\title{
Omjer širine i visine lica političara i uspjeh na političkim izborima
}

\author{
Irena Pavela Banai \\ Sveučilište u Zadru, Odjel za psihologiju, Zadar, Hrvatska \\ Benjamin Banai \\ Banai Analitika, obrt za obradu podataka, Zadar, Hrvatska \\ Mladen Mavar \\ Psihijatrijska bolnica Ugljan, Ugljan, Hrvatska
}

\begin{abstract}
Sažetak
Prijašnja su istraživanja pokazala da prilikom glasovanja na političkim izborima birači uzimaju u obzir fizičke karakteristike političkih kandidata. Primjerice, birači češće glasaju za političare koje na temelju lica percipiraju kao kompetentnije. Također, kandidati koji izgledaju dominantnije i muževnije imaju veću prednost kod konzervativnijih birača. Budući da se omjer širine i visine lica pokazao prediktorom procjena muževnosti i dominantnosti, cilj je ovoga istraživanja bio ispitati doprinos navedenoga omjera u predviđanju ishoda stvarnih političkih izbora. U tu je svrhu korištena baza digitalnih fotografija lica političkih kandidata za Kongres (Senat i Zastupnički dom) i mjesto guvernera Sjedinjenih Američkih Država, a koji se mogu podijeliti u dvije kategorije ovisno o pripadnosti Demokratskoj, odnosno Republikanskoj stranci. Na temelju prikupljenih fotografija izračunani su omjeri širine i visine lica za ukupno 259 kandidata i 52 kandidatkinje. Nizom linearnih i binarnih regresijskih analiza, uz kontrolu spola kandidata, pripadnosti stranci, tipa izbora te vrste kandidature (reizbor ili prva kandidatura), nije utvrđeno da omjer širine i visine lica predviđa ishod izbora i proporciju osvojenih glasova. U pokušaju objašnjenja neočekivanih nalaza u obzir je uzeto nekoliko aspekata s ciljem pružanja smjernica za buduća istraživanja.
\end{abstract}

Ključne riječi: omjer širine i visine lica, politički kandidati, izbori, ishod izbora

\section{Uvod}

Dosadašnja istraživanja $u$ području evolucijske političke psihologije pokazuju da se birači tijekom glasovanja na političkim izborima oslanjaju na

Irena Pavela Banai, Odjel za psihologiju, Sveučilište u Zadru, Obala kralja Petra Krešimira IV 2, 23000 Zadar, Hrvatska. E-pošta: ipavela@unizd.hr 
određene fizičke karakteristike političkih kandidata. Primjerice, u laboratorijskim je istraživanjima utvrđeno da glasači preferiraju političare s muževnijim glasom (Klofstad, 2016; Tigue i sur., 2012). Taj je nalaz potvrđen i u istraživanjima na stvarnim političkim izborima, gdje je pokazano da su kandidati s muževnijim glasom imali veću vjerojatnost pobjede na izborima (Banai i sur., 2017; Banai i sur., 2018; Pavela Banai i sur., 2017). Osim s glasom, ishod je izbora povezan i s izgledom kandidata. Primjerice, utvrđeno je da na temelju fotografija lica američkih političkih kandidata ljudi zaključuju o njihovoj kompetentnosti (Todorov i sur., 2005). Važno je naglasiti da su se procjene kompetentnosti temeljile isključivo na percepciji lica jer su politički kandidati bili nepoznati sudionicima istraživanja. Na temelju dobivenih procjena kompetentnosti u spomenutome istraživanju bilo je moguće predvidjeti pobjedu na održanim izborima. Specifično, Todorov i suradnici (2005) izvijestili su da postotak utrka za Senat u kojima je pobijedio kandidat koji je ujedno procijenjen kao kompetentniji iznosi $71.6 \%$.

Osim toga, birači generalno preferiraju privlačnije kandidate (Anderson i sur., 2001; Grammer i sur., 2003; Lenz i Lawson, 2011; White i sur., 2013). Također, utvrđena je tendencija biranja političkih kandidata s muževnim licem. Primjerice, sudionici su između dvojice kandidata birali onoga kojega su percipirali muževnijim, posebice u hipotetskoj situaciji rata u zemlji (Little i sur., 2007). Nadalje, u jednome je istraživanju na temelju fotografija članova Zastupničkoga doma Sjedinjenih Američkih Država izračunan indeks muževnosti za svakoga političara koji pripada Republikanskoj ili Demokratskoj stranci. Spomenuti je indeks dobiven na temelju antropometrijskih mjera crta lica. Sudionici istraživanja bili su skloniji dati svoj glas kandidatu Demokratske stranke s muževnijim licem (Carpinella i sur., 2016).

Dakle, birači pokazuju preferenciju muževnih političkih kandidata. Muževna obilježja glasa i lica muškaraca povezana su s višim razinama testosterona (Dabbs i Mallinger, 1999; Penton-Voak i Chen, 2004; Puts i sur., 2012; Roney i sur., 2006). Pretpostavlja se da se sklonost političkim vođama koji svojim obilježjima signaliziraju visoke razine testosterona razvila kao adaptivni mehanizam jer su visoke razine toga hormona indikator dominacije i društvenoga utjecaja (Mazur i Booth, 1998; Schaal i sur., 1996). Naime, tijekom evolucijske povijesti ljudi su se suočavali s problemima uspješne koordinacije u pronalaženju hrane, grupnome lovu, rješavanju unutargrupnih konflikata i međugrupnih sukoba. Članovi zajednice koji su imali veće fizičke sposobnosti ujedno su bili uspješniji u rješavanju navedenih problema te su češće bili birani za vođe (Johnson i Earle, 1987; Van Vugt i sur., 2008; Vandermassen, 2008; von Rueden i Van Vugt, 2015). Stoga se smatra da sličan mehanizam ljudi posjeduju i danas, a utvrđen je i u različitim kulturama (za detalje i pregled v. Banai i Penezić, 2018, 2019).

Nadalje, bitno je spomenuti da preferencija dominantnoga i muževnoga političkog vođe može ovisiti o percepciji sukoba u zajednici. Istraživanja 
pokazuju da su birači skloniji izboru političara muževnijega glasa i izgleda ako postoji prijetnja međugrupnoga sukoba (Laustsen i Petersen, 2015; Little i sur., 2007; Spisak i sur., 2012; Tigue i sur., 2012). Navedeni je nalaz potvrđen i na uzorku lica političarki, pri čemu su sudionici preferirali kandidatkinje muževnijega lica u hipotetskoj situaciji rata (Ferguson i sur., 2019; Spisak i sur., 2012). Spisak i suradnici (2012) također naglašavaju da je za predviđanje preferencija vođe važnija percipirana muževnost lica vođe od samoga spola vođe. Izbor muževnoga vođe pod prijetnjom sukoba objašnjava se tendencijom birača da izaberu vođu koji je dorastao trenutnim zahtjevima zadatka u zajednici, odnosno uspješnoj obrani od opasnosti. Specifično, muževni se vođa percipira kao osoba sposobna riješiti konflikt i obraniti zajednicu upravo zbog svojih fizičkih predispozicija i dominacije. Kako je i ranije spomenuto, istraživanja pokazuju da muškarci s muževnijim crtama lica, temeljeno na antropometrijskim mjerama, imaju više razine testosterona nakon natjecanja u zadatku s drugim muškarcima (Pound i sur., 2009). Stoga Spisak i suradnici (2012) zaključuju da muževnost lica signalizira potencijal dobroga vođe tijekom međugrupnoga sukoba.

Osim o kontekstu, izbor dominantnoga vođe ovisi i o političkoj ideologiji biračkoga tijela. Pokazano je da su birači konzervativne političke ideologije skloniji promatrati svijet kao prijeteće i kompetitivno mjesto te su više orijentirani na socijalnu dominaciju (Duckitt i Sibley, 2010; Hibbing i sur., 2013; Laustsen i sur., 2015). Stoga više pokazuju preferenciju prema dominantnim i muževnim kandidatima od birača liberalne ideologije. Primjerice, Banai i suradnici (2018) izvijestili su da političari muževnoga glasa, odnosno niže frekvencije, imaju veću vjerojatnost pobjede na izborima u konzervativnijim državama. Kada je riječ o muževnosti lica, Laustsen i Petersen (2015), koristeći digitalno kreirana muževna i ženstvena prototipna lica muškaraca, utvrdili su da su konzervativniji sudionici skloniji izboru muževnoga kandidata. Slični su rezultati dobiveni istraživanjem u kontekstu političkih stranaka. Naime, utvrđeno je da se desno i lijevo orijentirane stranke razlikuju u poretku kandidata na biračkome listiću ovisno o muževnosti kandidata. U usporedbi s lijevo orijentiranim strankama, desno orijentirane stranke imaju veću sklonost postavljanju dominantnoga kandidata na višu poziciju na biračkome listiću (Laustsen i Petersen, 2018).

$\mathrm{Na}$ temelju opisanih nalaza može se reći da se birači oslanjaju na fizičke (muževne) karakteristike kandidata prilikom izbora političkoga vođe. Pritom je većina dosadašnjih istraživanja bila usmjerena na ulogu glasa i lica kandidata u izbornome procesu. Dok je u istraživanjima odnosa glasa i izbornoga uspjeha utvrđeno da je visina glasa glavna značajka koja doprinosi povećanju uspješnosti (Banai i sur., 2017; Banai i sur., 2018; Pavela Banai i sur., 2017), iz rezultata istraživanja lica političara nije u potpunosti jasno koja točno fizička značajka povećava uspjeh. Budući da je dosad fokus bio uglavnom na procjenama i percepciji lica političara u kontekstu političkih izbora, u literaturi nedostaje 
istraživanja odnosa objektivnih morfoloških karakteristika lica političara i njihova uspjeha na izborima.

Jedna od morfoloških značajki lica koja bi mogla biti povezana s ishodom izbora omjer je širine i visine lica (engl. facial width-to-height ratio, fWHR). fWHR se dobiva izračunavanjem omjera između maksimalne horizontalne udaljenosti između lijeve i desne strane lica mjereno na zigomatskoj kosti (širina lica) i vertikalne udaljenosti od gornje središnje točke usana do najviše točke na kapcima (visina lica). Pretpostavka da bi fWHR mogao biti povezan s uspjehom na političkim izborima temelji se na rezultatima nekoliko prijašnjih istraživanja. Prvo, kao i za ljudski glas, utvrđeno je da je fWHR spolno dimorfna značajka, pri čemu muškarci imaju veći omjer od žena (Carré i McCormick, 2008; Geniole i sur., 2015). Potvrđeno je također da je fWHR pozitivno povezan s razinama testosterona (Lefevre i sur., 2013). Nadalje, fWHR je pozitivno povezan s percepcijom dominantnosti (Valentine i sur., 2014), muževnosti, prijetećega izgleda (Geniole i sur., 2015) i fizičke snage (Windhager i sur., 2011). Osim toga, omjer je pozitivno povezan sa stvarnim borilačkim sposobnostima muškaraca (Třebický i sur., 2015; Zilioli i sur., 2015) te potencijalom za fizičku prijetnju operacionaliziranim kao veličina bicepsa (MacDonell i sur., 2018). Uz navedeno, fWHR je pozitivno povezan sa samoprocjenom moći (Haselhuhn i Wong, 2012), dominantnosti i agresije kod obaju spolova (Lefevre i sur., 2014). Usto, provedeno je istraživanje u kojemu su uspoređene fotografije izvršnih direktora vodećih tvrtki u Velikoj Britaniji i kontrolne fotografije drugih muškaraca slične dobi. Utvrđeno je da izvršni direktori imaju viši fWHR u usporedbi s drugim muškarcima slične dobi (Alrajih i Ward, 2014). U istome je istraživanju dobiveno da sudionici izvršne direktore percipiraju kao dominantnije i uspješnije od drugih muškaraca te da je fWHR pozitivno povezan s percepcijom dominantnosti i uspješnosti. Kad je riječ o političkim kandidatima, potvrđeno je da je fWHR, izmjeren na uzorku lica bivših američkih predsjednika, pozitivno povezan $\mathrm{s}$ percepcijom motivacije za postignućem $(r=.58)$ (Lewis i sur., 2012). Kao izvor stupnja motivacije za postignućem korištena je analiza osobina ličnosti bivših američkih predsjednika, a koja se temeljila na brojnim povijesnim tekstovima i biografskim i političkim podacima (za detalje v. Simonton, 1986).

Međutim, na temelju dostupne literature, čini se da dosad nije ispitana i direktna veza fWHR-a i stvarnoga uspjeha političkih kandidata, odnosno uspjeha na političkim izborima. Navedeno čini glavno polazište za trenutno istraživanje. Ispitivanje uloge fWHR-a u političkome uspjehu može upotpuniti dosadašnje nalaze koji nedvosmisleno pokazuju da su izgled i percepcija lica povezani s izbornim ishodom. Pritom se naglasak u ovome radu stavlja na objektivne morfološke karakteristike lice umjesto na samu percepciju lica. Nadalje, koristeći fWHR kao mjeru muževnosti lica, ovo istraživanje doprinosi raspravi o značaju te morfološke karakteristike u takvim vrstama studija.

Dakle, na temelju opisanih nalaza i utvrđenih pozitivnih povezanosti između 
fWHR-a i percepcije osobina i ponašanja koja bi mogla biti važna za izbor političkoga vođe, cilj je ovoga istraživanja utvrditi doprinos fWHR-a u predviđanju ishoda održanih političkih izbora, uzimajući u obzir političku ideologiju stranke kojoj kandidati pripadaju. U tu su svrhu korištene dostupne fotografije kandidata za Kongres (Senat i Zastupnički dom) i mjesto guvernera Sjedinjenih Američkih Država. Kandidati se mogu podijeliti u dvije kategorije ovisno o pripadnosti jednoj od dvije vodeće stranke u SAD-u, Republikancima (konzervativnima) i Demokratima (liberalnima). Glavna je pretpostavka da će kandidati višega fWHR-a imati veću vjerojatnost pobjede na izborima i veću proporciju osvojenih glasova, pri čemu se očekivao veći efekt za kandidate koji pripadaju Republikanskoj stranci. Kada je riječ o spolu kandidata, očekuju se razlike u fWHR-u između muškaraca i žena s obzirom na to da se ta karakteristika lica smatra spolno dimorfnom (Carré i McCormick, 2008; Geniole i sur., 2015). Međutim, uzimajući u obzir rezultate ranijega istraživanja (Spisak i sur., 2012), očekuje se da će doprinos fWHR-a u predviđanju izborne uspješnosti biti jednak za oba spola.

\section{Metoda}

\section{Fotografije političkih kandidata}

U ovome je istraživanju korištena javno dostupna baza digitalnih fotografija lica političara iz Sjedinjenih Američkih Država. Baza je kreirana tijekom prethodnih istraživanja u kojima je proučavana povezanost percipirane kompetentnosti političkih kandidata i uspjeha na izborima (Balew i Todorov, 2007; Olivola i Todorov, 2010; Todorov i sur., 2005). U toj su bazi prikupljene fotografije lica političara koji su se u različitim saveznim državama kandidirali za Kongres (za mjesto u Senatu u razdoblju od 2000. do 2004. godine te za mjesto u Zastupničkome domu u razdoblju od 2002. do 2004. godine) i za mjesto guvernera u razdoblju od 1995. do 2006. godine. Za svaku saveznu državu prikupljale su se informacije o dvama političarima između kojih se vodila utrka za poziciju.

Uz fotografiju lica političara u dostupnoj su bazi zabilježene informacije o spolu, rasi i etničkoj pripadnosti, stranci iz koje kandidat dolazi (Republikanska ili Demokratska stranka), tipu izbora (za Kongres ili mjesto guvernera), vrsti kandidature (reizbor ili prva kandidatura) te broju i proporciji osvojenih glasova na izborima.

Ukupno su prikupljene informacije o 492 političara, od kojih je 246 dolazilo iz Republikanske stranke, 241 iz Demokratske stranke, a samo 5 političara nije dolazilo ni iz jedne od dviju najvećih stranki u SAD-u.

$\mathrm{S}$ obzirom da su se na fotografijama radile analize morfologije lica, trebalo je biti zadovoljeno nekoliko kriterija. Prvo, osoba je na fotografiji morala biti 
frontalno okrenuta prema fotoaparatu te su se izuzimale one fotografije u kojima je lice bilo okrenuto u poluprofil. Drugo, lice je moralo biti postavljeno uspravno te je provjeravano je li linija koja povezuje dvije najniže točke obrva postavljena horizontalno. Treće, lice je moralo biti dovoljno osvijetljeno da na njemu nema sjena, a na fotografiji nisu smjeli biti drugi objekti koji bi prekrivali površinu lica. Vodeći se opisanim kriterijima autori su za potrebe ovoga istraživanja pregledali sve fotografije iz baze i procijenili koliko je svaka od njih adekvatna za analizu oblika lica. U daljnje su analize uvrštene fotografije lica za koje je postojala potpuna sukladnost s prikladnošću za analizu oblika lica. Nakon toga koraka u bazi je fotografija ostalo 329 lica političara.

Prije provođenja daljnjih analiza lica pregledana je učestalost različitih demografskih obilježja kandidata. Svrha je toga koraka bila izbacivanje iz uzorka kandidata $s$ relativno rijetkim obilježjima koja bi mogla utjecati na konačne rezultate. Za početak, dva su se političara kandidirala kao nezavisni kandidati, a jedan kao član Libertarijanske stranke. Njihove su fotografije izbačene iz uzorka. Zatim, u uzorku je postojao relativno mali broj pripadnika rasnih, odnosno etničkih manjina (Amerikanci afričkoga, azijskoga ili latinoameričkog podrijetla). Slijedeći metodologiju prijašnjih istraživanja (npr. Re i Rule, 2016) iz baze su izbačene fotografije ukupno 14 kandidata koji su bili pripadnici rasne ili etničke manjine zbog toga što imaju različitu morfologiju lica u usporedbi s kandidatima bijele rase.

Nakraju se u konačnome uzorku na kojemu su provedene analize oblika lica nalazilo ukupno 311 političkih kandidata, od kojih su 259 muškoga, a 52 ženskoga spola. Kad je riječ o tipu izbora, 154 političara kandidirala su se za Kongres, a njih 157 za poziciju guvernera. Uzme li se u obzir pripadnost stranci, 150 kandidata je iz Demokratske, a 161 je iz Republikanske stranke. Vezano uz vrstu kandidature, 121 kandidat bio je na reizboru, a 190 ih se kandidiralo prvi put.

\section{Izračunavanje omjera širine i visine lica}

Fotografije lica analizirane su pomoću računalnoga programa ImageJ2 (Rueden i sur., 2017), besplatnoga programa koji je osmišljen kao alat za analizu digitalnih snimki u prirodnim znanostima poput biologije ili fizike. Pomoću toga programa izmjerene su širina i visina lica u pikselima, na temelju čega je izračunan fWHR dijeljenjem vrijednosti širine s vrijednošću visine lica. Širina i visina lica bile su definirane prema opisu u ranijim istraživanjima (Carré i McCormick, 2008). Širina lica operacionalizirana je kao udaljenost između dvaju zygiona, najizbočenijih točaka na luku jagodične kosti lica (os zygomaticum) s lijeve i s desne strane. Visina lica operacionalizirana je kao udaljenost između labiale superiusa, gornje središnje točke linije usana, te superciliary mediale, najviše medijalne točke obrva. 


\section{Rezultati}

\section{Analitička strategija}

Sve su analize provedene pomoću programskoga jezika za statističku obradu podataka $R$ v.6.6.0 (R Core Team, 2019) te paketa Resourceselection v. 0.3-5 (Lele i sur., 2019). Kako bi se utvrdilo postoji li povezanost fWHR-a i uspjeha na održanim političkim izborima, proveden je niz binarnih logističkih i linearnih regresijskih modela. U svim binarnim logističkim modelima kriterijska varijabla uspjeh na izborima definirana je kao ishod izbora (pobjeda - poraz), dok je u linearnim regresijskim analizama kriterijska varijabla bila proporcija osvojenih glasova.

U svaki je regresijski model uvršteno i nekoliko kontrolnih varijabli. Uvrštena je varijabla tip izbora (Kongres ili mjesto guvernera). Razlog kontrole te varijable nalazi su prijašnjega istraživanja glasa kandidata kao prediktora uspjeha na ukupno 69 političkih izbora održanih diljem svijeta (Banai i sur., 2018). Naime, utvrđeno je da je frekvencija glasa značajan prediktor uspjeha samo predsjedničkih kandidata, a ne i kandidata na parlamentarnim izborima. Shodno tomu uključivanjem tipa izbora omogućena je kontrola te varijable.

Nadalje, uključivanjem spola kandidata kao kontrolne varijable nastojao se kontrolirati potencijalno različit efekt fWHR-a u predviđanju političkoga uspjeha muškaraca i žena. Također, kontrolirana je pristranost prema aktualnoj vlasti (engl. incumbency bias, Gelman i King, 1990) zbog koje je moguće da političari koji su na reizboru za poziciju na kojoj se nalaze imaju veću vjerojatnost pobjede. Stoga je u svrhu kontrole pristranosti prema trenutnoj vlasti uvrštena varijabla vrsta kandidature (reizbor ili prva kandidatura).

Dodatno, u svakoj je regresijskoj analizi u drugome koraku u model uvedena i interakcija fWHR-a i pripadnosti stranci. S obzirom na prethodna istraživanja, moguće je očekivati veću preferenciju muževnih kandidata (kandidata s višim fWHR-om) među konzervativnim biračima te veću preferenciju kandidata $\mathrm{s}$ ženstvenim obilježjima lica (kandidata s nižim fWHR-om) među liberalnim biračima. Prema tome, moguće je očekivati i da će nagibi regresijskih pravaca za kandidate koji dolaze iz Republikanske i Demokratske stranke biti različiti.

U Tablici 1. navedeni su broj i postotak političara ovisno o kontrolnim varijablama uključenima u regresijske modele. 
Tablica 1.

Broj i postotak političkih kandidata ovisno o tipu izbora, spolu, pripadnosti stranci te vrsti kandidature

\begin{tabular}{llrc}
\hline & & $n$ & $\%$ \\
\hline \multirow{2}{*}{ Tip izbora } & Kongres & 154 & 49.52 \\
& Mjesto guvernera & 157 & 50.48 \\
\hline \multirow{2}{*}{ Spol } & Muškarci & 259 & 83.28 \\
& Žene & 52 & 16.72 \\
\hline \multirow{2}{*}{ Stranka } & Demokratska & 150 & 48.23 \\
& Republikanska & 161 & 51.77 \\
\multirow{2}{*}{ Vrsta kandidature } & Reizbor & 121 & 38.90 \\
& Prva kandidatura & 190 & 61.10 \\
\hline
\end{tabular}

Kad je riječ o glavnoj prediktorskoj varijabli, fWHR-u, prosječna vrijednost $(M=1.92, S D=0.17)$ slična je kao u prethodnim istraživanjima (Carré i McCormick, 2008; Lefevre i sur., 2014), a indeksi asimetrije $(I A=0.45)$ i spljoštenosti $(I S=0.21)$ ukazuju da distribucija ne odstupa bitno od teorijski normalne (Kline, 2011). Također, budući da je prema nekim dosadašnjim istraživanjima fWHR spolno dimorfna značajka (Carré i McCormick, 2008; Geniole i sur., 2015), pri čemu je omjer veći kod muškaraca, inicijalno su provjerene razlike između političkih kandidata $(M=1.92, S D=0.17)$ i kandidatkinja $(M=1.92, S D=0.16)$. Zbog nejednake veličine uzorka kandidata muškoga i ženskog spola razlika je provjerena Welchovim testom te se pokazalo da nije statistički značajna (Welch's $t=0.07, d f=78.22, p>.05$ ).

\section{fWHR u predviđanju ishoda političkih izbora}

U prvim je analizama binarnom logističkom regresijom ispitano je li fWHR povezan $\mathrm{s}$ većom vjerojatnošću pobjede na političkim izborima, pri čemu je kriterijska varijabla bila ishod izbora (pobjeda - poraz). Svaki regresijski model najprije je evaluiran pomoću Hosmer-Lemeshowljeva testa prikladnosti modela podacima (Hosmer i sur., 2013). U svojoj osnovi taj je test hi-kvadrat test prilagođen provjeravanju prikladnosti modela binarne logističke regresije, te ako vrijednost hi-kvadrata nije statistički značajna $(p>0.05)$, model se smatra prikladnim, a dobiveni regresijski koeficijenti interpretabilnima.

$\mathrm{U}$ Tablici 2. prikazani su rezultati binarne logističke regresijske analize $u$ svrhu ispitivanja doprinosa fWHR-a u predviđanju ishoda izbora, uz kontrolu tipa izbora, spola kandidata, pripadnosti stranci te vrste kandidature. 
Tablica 2.

Rezultati binarne logističke regresijske analize za ispitivanje doprinosa fWHR-a u predviđanju ishoda izbora s obzirom na tip izbora, spol kandidata, pripadnost stranci te vrstu kandidature

\begin{tabular}{|c|c|c|c|c|c|c|}
\hline \multirow{2}{*}{ Prediktori } & \multicolumn{3}{|c|}{ Model 1} & \multicolumn{3}{|c|}{ Model 2} \\
\hline & $B$ & $95 \% C I$ & $p$ & $B$ & $95 \% C I$ & $p$ \\
\hline Odsječak & 0.08 & $-0.48-0.64$ & .778 & 0.09 & $-0.71-0.88$ & .834 \\
\hline fWHR & 0.12 & $-0.17-0.40$ & .421 & 0.12 & $-0.30-0.53$ & .582 \\
\hline Tip izbora & 0.08 & $-0.02-0.18$ & .115 & 0.08 & $-0.02-0.18$ & .115 \\
\hline Spol & -0.02 & $-0.15-0.10$ & .707 & -0.02 & $-0.15-0.10$ & .708 \\
\hline $\begin{array}{l}\text { Pripadnost } \\
\text { stranci }\end{array}$ & -0.02 & $-0.12-0.07$ & .612 & -0.03 & $-1.14-1.07$ & .953 \\
\hline $\begin{array}{l}\text { Vrsta } \\
\text { kandidature }\end{array}$ & 0.54 & $0.44-0.64$ & $<.001$ & 0.54 & $0.44-0.64$ & $<.001$ \\
\hline $\begin{array}{l}\text { fWHR * } \\
\text { Pripadnost } \\
\text { stranci }\end{array}$ & & & & 0.00 & $-0.57-0.58$ & .988 \\
\hline $\begin{array}{l}\text { Nagelkerkeov } \\
R^{2}\end{array}$ & & .295 & & & .295 & \\
\hline
\end{tabular}

Hosmer-

Lemeshowljev $\quad \chi^{2}=3.1, s s=8, p>0.05 \quad \chi^{2}=3.1, s s=8, p>0.05$ test

Napomena: Tip izbora - referentna vrijednost „Kongres“; Spol - referentna vrijednost „Muški“; Pripadnost stranci - referentna vrijednost „Demokratska“; Vrsta kandidature - referentna vrijednost „Prva kandidatura“; $B$ - nestandardizirani regresijski koeficijent; $95 \% C I-95 \%$ granice pouzdanosti.

Iz Tablice 2. (Model 1) vidljivo je da fWHR nije povezan s većom vjerojatnošću pobjede ili poraza na izborima. Nadalje, provjerena je i interakcija stranačke pripadnosti i fWHR-a u predviđanju ishoda izbora. Rezultati pokazuju da interakcijski efekt nije statistički značajan te da regresijski model s dodanim interakcijskim efektom ne pokazuje porast u pseudo $R^{2}\left(\Delta\right.$ Nagelkerke $\left.R^{2}=0\right)$ (Tablica 2., Model 2).

Nadalje, u daljnjim su analizama provjereni dodatni interakcijski efekti ostalih kontrolnih varijabli i fWHR-a. Nije utvrđen interakcijski efekt tipa izbora i fWHR-a na ishod izbora $\left(\chi^{2}=2.7, s s=8, p>0.05, B=0.21,95 \%\right.$ CI [-0.790.36], $p>0.05)$, kao ni interakcijski efekt spola kandidata i fWHR-a na ishod izbora $\left(\chi^{2}=2.6, s s=8, p>0.05, B=-0.01,95 \% C I[-0.83-0.81], p>0.05\right)$.

\section{fWHR u predviđanju proporcije osvojenih glasova}

U sljedećim je analizama provjereno predviđa li fWHR proporciju glasova koje su kandidati/kandidatkinje osvojili na održanim izborima, uz kontrolu tipa izbora, spola kandidata, pripadnosti stranci te vrste kandidature. Rezultati su prikazani u Tablici 3 . 
Tablica 3.

Rezultati linearne regresijske analize za ispitivanje doprinosa fWHR-a u predviđanju proporcije osvojenih glasova s obzirom na tip izbora, spol kandidata, pripadnost stranci te vrstu kandidature

\begin{tabular}{lcccccc}
\hline \multirow{2}{*}{ Prediktori } & \multicolumn{3}{c}{ Model 1 } & \multicolumn{3}{c}{ Model 2 } \\
\cline { 2 - 7 } & $B$ & $95 \% C I$ & $p$ & $B$ & $95 \% C I$ & $p$ \\
\hline Odsječak & 0.45 & $0.28-0.61$ & $<.001$ & 0.35 & $0.12-0.59$ & .003 \\
\hline fWHR & 0.02 & $-0.07-0.10$ & .694 & 0.07 & $-0.06-0.19$ & .287 \\
\hline Tip izbora & 0.00 & $-0.03-0.03$ & .954 & 0.18 & $-0.14-0.50$ & .269 \\
\hline Spol & 0.01 & $-0.02-0.04$ & .435 & 0.01 & $-0.02-0.04$ & .441 \\
\hline $\begin{array}{l}\text { Pripadnost } \\
\text { stranci }\end{array}$ & -0.01 & $-0.04-0.03$ & .706 & -0.01 & $-0.04-0.03$ & .722 \\
\hline $\begin{array}{l}\text { Vrsta } \\
\text { kandidature }\end{array}$ & 0.06 & $0.04-0.09$ & $<.001$ & 0.07 & $0.04-0.09$ & $<.001$ \\
\hline $\begin{array}{l}\text { fWHR * } \\
\text { Stranka }\end{array}$ & & & -0.09 & $-0.26-0.07$ & .270 \\
\hline $\begin{array}{l}R^{2} / \text { prilagođeni } \\
R^{2}\end{array}$ & \multicolumn{7}{c}{$.059 / .043$} & & $.063 / .044$ & \\
\hline ANOVA & $F(5,305)=3.81, p<0.01$ & $F(6,304)=3.38, p<0.01$ \\
\hline
\end{tabular}

Napomena: Tip izbora - referentna vrijednost „Kongres“; Spol - referentna vrijednost „Muški“; Pripadnost stranci - referentna vrijednost „Demokratska“; Vrsta kandidature - referentna vrijednost „Prva kandidatura“; $B$ - nestandardizirani regresijski koeficijent; $95 \% C I-95 \%$ granice pouzdanosti.

Kao u slučaju binarne logističke regresijske analize, pokazano je da fWHR nije značajan prediktor proporcije glasova osvojenih na izborima (Tablica 3., Model 1). Pored toga, taj odnos nije moderiran stranačkom pripadnošću kandidata/kandidatkinje s obzirom na to da interakcija pripadnosti stranci i fWHR-a nije značajna.

Nadalje, u daljnjim je analizama utvrđeno da odnos fWHR-a i proporcije glasova osvojenih na izborima nije moderiran ni tipom izbora $(F(6,304)=3.19$, $p<0.01 ; B=-0.03,95 \% C I[-0.20-0.14], p>0.05)$ kao ni spolom kandidata/kandidatkinje $(F(6,304)=3.55, p<0.01 ; B=-0.18,95 \% C I[-0.42-$ $0.06], p>0.05)$. Dakle, interakcije kontrolnih varijabli i fWHR-a nisu statistički značajne.

Iz provedenih se analiza zaključuje da fWHR nije povezan $\mathrm{s}$ ishodom političkih izbora te da ne doprinosi predviđanju proporcije osvojenih glasova. Navedeno jednako vrijedi za kandidate koji se kandidiraju za različite pozicije (Senat i mjesto Guvernera), za one koji su različitoga spola, koji dolaze iz različitih stranaka te neovisno o tome je li riječ o reizboru ili prvoj kandidaturi. 


\section{Rasprava}

Uzevši u obzir rezultate dosadašnjih istraživanja koji ukazuju na povezanost fWHR-a i percepcije te samoprocjene osobina koje bi mogle biti važne za političkoga vođu (Geniole i sur., 2015; Haselhuhn i Wong, 2012; Lefevre i sur., 2014; Lewis i sur., 2012; MacDonell i sur., 2018; Třebický i sur., 2015; Valentine i sur., 2014; Windhager i sur., 2011; Zilioli i sur., 2015), u ovome je istraživanju provjereno može li fWHR predvidjeti ishod izbora na uzorku američkih političkih kandidata. Pretpostavka da će kandidati s većim fWHR-om imati veću vjerojatnost pobjede i veću proporciju osvojenih glasova birača nije potvrđena. Isto vrijedi i za republikanske i za demokratske kandidate, neovisno o spolu, tipu izbora i vrsti kandidature.

U pokušaju objašnjenja toga neočekivanog nalaza rezultati će se interpretirati uzimajući u obzir nekoliko aspekata korištenja fWHR-a kao morfološke mjere lica. Prvo, iako je ranije utvrđeno da je fWHR spolno dimorfna značajka lica (Carré i McCormick, 2008; Geniole i sur., 2015), u ovome istraživanju nije utvrđena razlika između političkih kandidata i kandidatkinja. Očekivane spolne razlike nisu utvrđene ni u istraživanju Özenera (2012) na uzorku sudionika iz Turske, kao ni u istraživanju Lefevre i suradnika (2012) na uzorku bijelaca mlađe i starije dobi te na uzorku crnaca mlađe životne dobi. Lefevre i suradnici (2012) stoga navode da su prijašnje razlike u fWHR-u lažno pozitivni rezultati uslijed korištenja maloga uzorka te neadekvatne kontrole etničke pripadnosti sudionika. Iz navedenoga proizlazi da fWHR možda nije spolno dimorfna značajka te da, slijedom toga, nije adekvatna fizička karakteristika koja bi mogla predvidjeti uspjeh na političkim izborima. Naime, nalazi koji su upućivali na to da je fWHR spolno dimorfna karakteristika predstavljaju jedno od polazišta i razloga zbog kojih je ta mjera uključena kao potencijalni prediktor ishoda izbora. Prijašnja istraživanja fizičkih značajki (npr. frekvencije glasa) koje su se pokazale prediktivnima za političku uspješnost dokazala su da su one spolno dimorfne (Banai i sur., 2017; Banai i sur., 2018; Pavela Banai i sur., 2017). Slijedom navedenoga, upitna spolna dimorfnost fWHR-a dovodi u pitanje i adekvatnost proučavanja te značajke kao prediktora uspjeha na političkim izborima, tim više što ni na uzorku u ovome istraživanju nisu pronađene razlike između muških i ženskih kandidata. Međutim, potrebno je osvrnuti se na još jednu mogućnost i uzrok nepostojanja spolnih razlika u fWHR-u u ovome istraživanju. Činjenica je da je zastupljenost žena u visokoj politici iznimno niska te je moguće da su žene koje obnašaju političku funkciju selekcionirane po nekim karakteristikama te samim time ne predstavljaju reprezentativnu skupinu. Dakle, predlažemo mogućnost da žene na političkim funkcijama imaju određene muževne značajke, što doprinosi smanjenju spolnih razlika u spolno dimorfnim fizičkim atributima.

Drugo, noviji podaci sugeriraju da je odnos fWHR-a i samoprocjena osobina poput fizičke agresije i dominacije moderiran društvenim statusom definiranim 
kao mjesečna razina prihoda (Noser i sur., 2018). Specifično, povezanost fWHRa i osobina vezanih uz dominaciju uočena je samo kod muškaraca nižega društvenog statusa. Navedeni nalaz autori objašnjavaju uzimajući u obzir da se agresivna i dominantna ponašanja, koja su pozitivno povezana s fWHR-om (Geniole i sur., 2015), manifestiraju u situacijama koje zahtijevaju iskazivanje moći. Predlažu mogućnost da muškarci visokoga socioekonomskog statusa nemaju razloga iskazivati agresivna i dominantna ponašanja jer imaju zadovoljen motiv za moći (za detalje v. Noser i sur., 2018). Slijedom navedenoga, povezanost će fWHR-a i navedenih ponašanja izostati. U ovome istraživanju korištene su fotografije političara za koje se može pretpostaviti da ne pripadaju skupini nižega socioekonomskog statusa. Stoga je moguće da fWHR u toj skupini sudionika, izrazito homogenoj prema društvenome položaju, ne pridonosi njihovu uspjehu.

Treće, neki nalazi upućuju na to da nakupljanje masnoga tkiva, odnosno adipozitet lica može umjetno povećati fWHR (Lefevre i sur., 2013). U skladu s time pronađena je pozitivna povezanost fWHR-a i percepcije adipoziteta (Valentine i sur., 2014). Slično tomu, omjer je pozitivno povezan i s indeksom tjelesne mase (Coetzee i sur., 2010). Navedeno je moglo utjecati na trenutne nalaze te je stoga preporuka za buduća istraživanja kontrolirati stvarnu ili percipiranu razinu masnoga tkiva na licima, kao i indeks tjelesne mase. Vezano uz konkretne prijedloge i metodološke smjernice za buduća istraživanja, korisno je napomenuti da bi prikupljanje podataka o stvarnim razinama adipoziteta $i$ indeksa tjelesne mase moglo biti otežano ako je riječ o stvarnim kandidatima na visokim političkim funkcijama. Pitanje je koliko bi njih dobrovoljno ustupilo te podatke u svrhu istraživanja. Drugi način kontrole može uključivati digitalnu manipulaciju adipoziteta lica i eksperimentalne provjere zasebnih efekata adipoziteta i fWHR-a na vjerojatnost pobjede na hipotetskim izborima. Također, moguće je ispitati i percipiranu razinu adipoziteta/indeksa tjelesne mase koristeći fotografije stvarnih kandidata te naknadno uvesti dodatne kontrole te varijable $\mathrm{u}$ statističke modele.

Četvrto, glavno su polazište za ovo istraživanje nalazi prijašnjih studija koji upućuju na povezanost fWHR-a i karakteristika koje bi teorijski mogle pridonijeti izbornomu uspjehu, poput dominantnosti, agresije i fizičke snage (Geniole i sur., 2015; Haselhuhn i Wong, 2012; Lefevre i sur., 2014; Lewis i sur., 2012; MacDonell i sur., 2018; Třebický i sur., 2015; Valentine i sur., 2014; Windhager i sur., 2011; Zilioli i sur., 2015). Međutim, Kosinski (2017) navodi da su povezanosti fWHR-a i određene vrste ponašanja pronađene u prijašnjim istraživanjima proizvodi maloga uzroka te naglašava da je značajnost tih efekata tek nešto malo ispod razine rizika od pogrešnoga zaključivanja od $5 \%$. Na velikome uzorku od 137163 sudionika taj autor nije replicirao povezanost te morfološke mjere i ponašajnih tendencija. Stoga je moguće da fWHR nije adekvatna mjera za ispitivanje odnosa crta lica i različitih aspekata ponašanja. Slično tomu, u ispitivanju odnosa fWHR-a i seksualnoga ponašanja Zhang i 
suradnici (2018) nisu uspjeli replicirati povezanost na velikome uzorku sudionika te također naglašavaju problem replikabilnosti i činjenicu da su povezanosti te morfološke mjere i ponašanja osjetljive na veličinu uzorka.

Jedna je od mogućnosti da je ta mjera koja se dobiva na osnovi 2D-fotografija posebno sklona pogrešci mjerenja. Primjerice, male promjene u položaju i nagibu glave ili izrazu lica mogu utjecati na vrijednosti fWHR-a. Neke od drugih mjera koje bi mogle biti korištene u budućim istraživanjima omjer su visine donjega dijela lica (od visine očiju do brade) i visine lica (od vrha čela do brade) te izraženost jagodičnih kostiju. Iako gotovo da i nisu zastupljene $u$ istraživanjima $u$ tome području, pokazano je da su te karakteristike spolno dimorfne (Lefevre i sur., 2012). Ipak, i te morfološke mjere mogu biti izložene pogrešci jer je riječ mjerenju na 2D-fotografijama. Stoga bi prikladnije bilo uzeti u obzir i kreirati 3D-modele lica na temelju niza fotografija iz više različitih kutova te na taj način dobiti preciznije podatke kao u nekim prijašnjim istraživanjima (npr. Henderson i sur., 2016). Međutim, u području ispitivanja lica stvarnih političara 3D-modeliranje lica moglo bi biti otežano zbog nedostupnosti fotografija.

Bitno je također napomenuti da je ovo jedno od rijetkih istraživanja koja se temelje na fotografijama stvarnih političara i stvarnih izbora. $\mathrm{Na}$ taj način povećana je ekološka valjanost u usporedbi s dosadašnjim laboratorijskim istraživanjima koja su se temeljila na digitalno manipuliranim fotografijama i eksperimentalnoj simulaciji političkoga izbornog procesa. Unatoč potencijalnomu problemu smanjenja kontrole kod korištenja fotografija stvarnih političkih kandidata u odnosu na digitalnu manipulaciju fotografija, može se zaključiti da ovo istraživanje povećanjem ekološke valjanosti daje značajan doprinos relativno novomu području evolucijske političke psihologije.

Zaključno, u ovome istraživanju nisu utvrđene povezanosti fWHR-a političkih kandidata i uspjeha na stvarnima političkim izborima koji je definiran kao ishod izbora i proporcija osvojenih glasova. Stoga su potrebna daljnja istraživanja te unaprjeđenje metodoloških mjera kako bi se utvrdilo koja fizička značajka lica doprinosi percepciji kompetentnosti i dominantnosti političara, a što posljedično predviđa njihov uspjeh na političkim izborima.

\section{Literatura}

Alrajih, S. i Ward, J. (2014). Increased facial width-to-height ratio and perceived dominance in the faces of the UK's leading business leaders. British Journal of Psychology, 105(2), 153-161. https://doi.org/ 10.1111/bjop.12035

Anderson, C., John, O. P., Keltner, D. i Kring, A. M. (2001). Who attains social status? Effects of personality and physical attractiveness in social groups. Journal of Personality and Social Psychology, 81(1), 116-132. https://doi.org/ 10.1037/00223514.81.1.116 
Ballew, C. C. i Todorov, A. (2007). Predicting political elections from rapid and unreflective face judgments. Proceedings of the National Academy of Sciences of the USA, 104(46), 17948-17953. https://doi.org/10.1073/pnas.0705435104

Banai, B., Laustsen, L., Pavela Banai, I. i Bovan, K. (2018). Presidential, but not prime minister, candidates with lower pitched voices stand a better chance of winning the election in conservative countries. Evolutionary Psychology, 16(2), 1-12. https://doi.org/10.1177/1474704918758736

Banai, B., Pavela Banai, I. i Bovan, K. (2017). Candidates' voice in political debates and the outcome of presidential elections. U: I. Burić (Ur.), 20th Psychology Days in Zadar; Book of Selected Proceedings (str. 33-39). Sveučilište u Zadru.

Banai, B. i Penezić, Z. (2018). Podrijetlo vodstva: Evolucijski pogled na odnos vođa i njihovih sljedbenika. Suvremena psihologija, 21(2), 141-160. https://doi.org/10. 21465/2018-SP-212-03

Banai, B. i Penezić, Z. (2019). Kako izgleda vođa? Evolucijski pogled na pristranosti prema obilježjima lica vođa. Psihologijske teme, 28(3), 549-566. https://doi.org/ 10.31820/pt.28.3.5

Carpinella, C. M., Hehman, E., Freeman, J. B. i Johnson, K. L. (2016). The gendered face of partisan politics: Consequences of facial sex typicality for vote choice. Political Communication, 33(1), 21-38. https://doi.org/10.1080/10584609.2014.958260

Carré, J. M. i McCormick, C. M. (2008). In your face: Facial metrics predict aggressive behaviour in the laboratory and in varsity and professional hockey players. Proceedings of the Royal Society B: Biological Sciences, 275(1651), 2651-2656. https://doi.org/10.1098/rspb.2008.0873

Coetzee, V., Chen, J., Perrett, D. I. i Stephen, I. D. (2010). Deciphering faces: Quantifiable visual cues to weight. Perception, 39(1), 51-61. https://doi.org/10.1068/p6560

Dabbs, J. M. Jr. i Mallinger, A. (1999). High testosterone levels predict low voice pitchamong men. Personality and Individual Differences, 27(4), 801-804. https://doi.org/10.1016/S0191-8869(98)00272-4

Duckitt, J. i Sibley, C. G. (2010). Personality, ideology, prejudice, and politics: A dualprocess motivational model. Journal of Personality, 78(6), 1861-1894. https://doi. org/10.1111/j.1467-6494.2010.00672.x

Ferguson, H. S., Owen, A., Hahn, A. C., Torrance, J., DeBruine, L. M. i Jones, B. C. (2019). Context-specific effects of facial dominance and trustworthiness on hypothetical leadership decisions. PLOS ONE, 14(7), e0214261. https://doi.org/10. 1371/journal.pone.0214261

Gelman, A. i King, G. (1990). Estimating incumbency advantage without bias. American Journal of Political Science, 34(4), 1142-1164.

Geniole, S. N., Denson, T. F., Dixson, B. J., Carré, J. M. i McCormick, C. M. (2015). Evidence from meta-analyses of the facial width-to-height ratio as an evolved cue of threat. PLOS ONE, 10(7), e0132726. https://doi.org/10.1371/journal.pone.0132726 
Grammer, K., Fink, B., Møller, A. P. i Thornhill, R. (2003). Darwinian aesthetics: Sexual selection and the biology of beauty. Biological Reviews, 78(3), 385-407. https://doi.org/10.1017/s1464793102006085

Haselhuhn, M. P. i Wong, E. M. (2012). Bad to the bone: Facial structure predicts unethical behaviour. Proceedings of the Royal Society B: Biological Sciences, 279(1728), 571-576. https://doi.org/10.1098/rspb.2011.1193

Henderson, A. J., Holzleitner, I. J., Talamas, S. N. i Perrett, D. I. (2016). Perception of health from facial cues. Philosophical Transactions of the Royal Society B: Biological Sciences, 371(1693), 20150380. https://doi.org/10.1098/rstb.2015.0380

Hibbing, J. R., Smith, K. B. i Alford, J. R. (2013). Predisposed: Liberals, conservatives, and the biology of political differences. Routledge.

Hosmer, D. W. Jr., Lemeshow, S. i Sturdivant, R. X. (2013). Applied logistic regression. John Wiley \& Sons.

Johnson, A. W. i Earle, T. (1987). The evolution of human societies. Stanford University Press.

Kline, R. B. (2011). Principles and practice of structural equation modelling. The Guilford Press.

Klofstad, C. A. (2016). Candidate voice pitch influences election outcomes. Political Psychology, 37(5), 725-738. https://doi.org/10.1111/pops.12280

Kosinski, M. (2017). Facial width-to-height ratio does not predict self-reported behavioral tendencies. Psychological Science, 28(11), 1675-1682. https://doi.org/10.1177/ 0956797617716929

Laustsen, L. i Petersen, M. B. (2015). Does a competent leader make a good friend? Conflict, ideology and the psychologies of friendship and followership. Evolution and Human Behavior, 36(4), 286-293. https://doi.org/10.1016/j.evolhumbehav. 2015.01.001

Laustsen, L. i Petersen, M. B. (2018). When the Party decides: The effects of facial competence and dominance on internal nominations of political candidates. Evolutionary Psychology, 16(2), 1-13. https://doi.org/10.1177/1474704917732005

Laustsen, L., Petersen, M. B. i Klofstad, C. A. (2015). Vote choice, ideology, and social dominance orientation influence preferences for lower pitched voices in political candidates. Evolutionary Psychology, 13, 1-13. https://doi.org/10.1177/ 1474704915600576

Lefevre, C. E., Etchells, P. J., Howell, E. C., Clark, A. P. i Penton-Voak, I. S. (2014). Facial width-to-height ratio predicts self-reported dominance and aggression in males and females, but a measure of masculinity does not. Biology Letters, 10(10), 20140729. https://doi.org/10.1098/rsbl.2014.0729

Lefevre, C. E., Lewis, G. J., Bates, T. C., Dzhelyova, M., Coetzee, V., Deary, I. J. i Perrett, D. I. (2012). No evidence for sexual dimorphism of facial width-to-height ratio in four large adult samples. Evolution and Human Behavior, 33(6), 623-627. https://doi.org/10.1016/j.evolhumbehav.2012.03.002 
Lefevre, C. E., Lewis, G. J., Perrett, D. I. i Penke, L. (2013). Telling facial metrics: Facial width-toheight ratio is associated with testosterone levels in men. Evolution and Human Behavior, 34, 273-279. https://doi.org/10.1016/j.evolhumbehav.2013. 03.005

Lele, S. R., Keim, J. K. i Solymos, P. (2019). ResourceSelection: Resource selection (probability) functions for use-availability data. $R$ package version 0.3-5. Preuzeto s: https://CRAN.R-project.org/package=ResourceSelection

Lenz, G. i Lawson, C. (2011). Looking the part: Television leads less informed citizens to vote based on candidates' appearance. American Journal of Political Science, 55, 574-589. https://doi.org/10.1111/j.1540-5907.2011.00511.x

Lewis, G. J., Lefevre, C. E. i Bates, T. C. (2012). Facial width-to-height ratio predicts achievement drive in US presidents. Personality and Individual Differences, 52(7), 855-857. https://doi.org/10.1016/j.paid.2011.12.030

Little, A. C., Burriss, R. P., Jones, B. C. i Roberts, S. C. (2007). Facial appearance affects voting decisions. Evolution and Human Behavior, 28(1), 18-27. https://doi.org/10. 1016/ j.evolhumbehav.2006.09.002

MacDonell, E. T., Geniole, S. N. i McCormick, C. M. (2018). Force versus fury: Sex differences in the relationships among physical and psychological threat potential, the facial width-to-height ratio, and judgements of aggressiveness. Aggressive Behavior, 44(5), 512-523. https://doi.org/10.1002/ab.21771

Mazur, A. i Booth, A. (1998). Testosterone and dominance in men. The Behavioral and Brain Sciences, 21, 353-363.

Noser, E., Schoch, J. i Ehlert, U. (2018). The influence of income and testosterone on the validity of facial width-to-height ratio as a biomarker for dominance. PLOS ONE, 13(11), e0207333. https://doi.org/10.1371/journal.pone.0207333

Olivola, C. Y. i Todorov, A. (2010). Elected in 100 milliseconds: Appearance-based trait inferences and voting. Journal of Nonverbal Behavior, 34, 83-110. https://doi.org/ 10.1007/s10919-009-0082-1

Özener, B. (2012). Facial width-to-height ratio in a Turkish population is not sexually dimorphic and is unrelated to aggressive behavior. Evolution and Human Behavior, 33(3), 169-173. https://doi.org/10.1016/j.evolhumbehav.2011.08.001

Pavela Banai, I., Banai, B. i Bovan, K. (2017). Vocal characteristics of presidential candidates can predict the outcome of actual elections. Evolution and Human Behavior, 38(3), 309-314. https://doi.org/10.1016/j.evolhumbehav.2016.10.012

Penton-Voak, I. S. i Chen, J. Y. (2004). High salivary testosterone is linked to masculine male facial appearance in humans. Evolution and Human Behavior, 25(4), 229-241. https://doi.org/10.1016/j.evolhumbehav.2004.04.003

Pound, N., Penton-Voak, I. S. i Surridge, A. K. (2009). Testosterone responses to competition in men are related to facial masculinity. Proceedings of the Royal Society B: Biological Sciences, 276, 153-159. 
Puts, D. A., Apicella, C. L. i Cárdenas, R. A. (2012). Masculine voices signal men's threat potential in forager and industrial societies. Proceedings of the Royal Society B: Biological Sciences, 279(1728), 601-609. https://doi.org/ 10.1098/rspb.2011.0829

$\mathrm{R}$ Core Team. (2019). R: A language and environment for statistical computing. $\mathrm{R}$ Foundation for Statistical Computing.

Re, D. E. i Rule, N. O. (2016). The big man has a big mouth: Mouth width correlates with perceived leadership ability and actual leadership performance. Journal of Experimental Social Psychology, 63, 86-93.

Roney, J. R., Hanson, K. N., Durante, K. M. i Maestripieri, D. (2006). Reading men's faces: Women's mate attractiveness judgments track men's testosterone and interest in infants. Proceedings of the Royal Society B: Biological Sciences, 273(1598), 2169-2175. https://doi.org/10.1098/rspb.2006.3569

Rueden, C. T., Schindelin, J., Hiner, M. C., DeZonia, B. E., Walter, A. E., Arena, E. T. i Eliceiri, K. W. (2017). ImageJ2: ImageJ for the next generation of scientific image data. BMC bioinformatics, 18(1), 529.

Schaal, B., Tremblay, R. E., Soussignan, R. i Susman, E. J. (1996). Male testosterone linked to high social dominance but low physical aggression in early adolescence. Journal of the American Academy of Child \& Adolescent Psychiatry, 35(10), 1322 1330.

Simonton, D. K. (1986). Presidential personality: Biographical use of the gough adjective check list. Journal of Personality and Social Psychology, 51, 149-160.

Spisak, B. R., Homan, A. C., Grabo, A. i Van Vugt, M. (2012). Facing the situation: Testing a biosocial contingency model of leadership in intergroup relations using masculine and feminine faces. The Leadership Quarterly, 23(2), 273-280. https://doi.org/ 10.1016/j.leaqua.2011.08.006

Tigue, C. C., Borak, D. J., O’Connor, J. J., Schandl, C. i Feinberg, D. R. (2012). Voice pitch influences voting behavior. Evolution and Human Behavior, 33(3), 210-216. https://doi.org/10.1016/j.evolhumbehav.2011.09.004

Todorov, A., Mandisodza, A. N., Goren, A. i Hall, C. C. (2005). Inferences of competence from faces predict election outcomes. Science, 308, 1623-1626. https://doi.org/10. 1126/science. 1110589

Třebický, V., Fialová, J., Kleisner, K., Roberts, S. C., Little, A. C. i Havlíček, J. (2015). Further evidence for links between facial width-to-height ratio and fighting success: Commentary on Zilioli et al. (2014). Aggressive Behavior, 41(4), 331-334.

Valentine, K. A., Li, N. P., Penke, L. i Perrett, D. I. (2014). Judging a man by the width of his face: The role of facial ratios and dominance in mate choice at speed-dating events. Psychological Science, 25(3), 806-811. https://doi.org/10.1177/ 0956797613511823

Van Vugt, M., Johnson, D., Kaiser, R. i O'Gorman, R. (2008). Evolution and the social psychology of leadership: The mismatch hypothesis. U: C. L. Hoyt, G. R. Goethals i D. R. Forsyth (Ur.), Leadership at the crossroads: Psychology and leadership (Vol. 1, str. 262-282). Praeger. 
Vandermassen, G. (2008). Can Darwinian feminism save female autonomy and leadership in egalitarian society? Sex Roles, 59(7-8), 482-491. https://doi.org/10.1007/s11199008-9478-3

von Rueden, C. i Van Vugt, M. (2015). Leadership in small-scale societies: Some implications for theory, research, and practice. The Leadership Quarterly, 26(6), 978-990. https://doi.org/10.1016/j.leaqua.2015.10.004

White, A. E., Kenrick, D. T. i Neuberg, S. L. (2013). Beauty at the ballot box: Disease threats predict preferences for physically attractive leaders. Psychological Science, 24(12), 2429-2436. https://doi.org/10.1177/0956797613493642

Windhager, S., Schaefer, K. i Fink, B. (2011). Geometric morphometrics of male facial shape in relation to physical strength and perceived attractiveness, dominance, and masculinity. American Journal of Human Biology, 23(6), 805-814. https://doi.org/ 10.1002/ajhb.21219

Zhang, W., Hahn, A. C., Cai, Z., Lee, A. J., Holzleitner, I. J., DeBruine, L. M. i Jones, B. C. (2018). No evidence that facial width-to-height ratio (fWHR) is associated with women's sexual desire. PLOS ONE, 13(7), e0200308. https://doi.org/10.1371/ journal. pone. 0200308

Zilioli, S., Sell, A. N., Stirrat, M., Jagore, J., Vickerman, W. i Watson, N. V. (2015). Face of a fighter: Bizygomatic width as a cue of formidability. Aggressive Behavior, 41(4), 322-330. https://doi.org/10.1002/ab.21544

\title{
Politicians' Facial Width-to-Height Ratio and their Electoral Success
}

\begin{abstract}
Previous studies have shown that during the election process voters rely on different physical characteristics of political candidates. For example, politicians who are perceived as more competent have greater electoral success. In addition, candidates who look more dominant and masculine are preferred among conservative voters. Since facial width-to-height ratio (fWHR) is assumed to be a predictor of perceived masculinity and dominance, this study aimed to investigate the contribution of fWHR in predicting the outcome of the real political elections. We used a digital database containing photographs of political candidates for the United States Senate (United States Congress and United States House of Representatives) and gubernatorial elections, representing Republican and Democratic Party. fWHR was calculated for the 259 male and 52 female candidates. Across several linear and binary regressions, with the control of the candidate's sex, party affiliation, election type and candidacy type (incumbency or first candidacy), fWHR predicted neither the election outcome nor the vote share. Several methodological aspects have been discussed to explain these unexpected findings and to give guidance for future research.
\end{abstract}

Keywords: facial width-to-height ratio, politicians, elections, vote share

Primljeno: 27. 2. 2020. 